The Syntax and Semantics of Russian Non-Sentence Adverbials

Lorentzen, Elena; Durst-Andersen, Per

Published in:

Scando-Slavica

DOI:

10.1080/00806765.2015.1109190

Publication date:

2015

Document version

Peer reviewed version

Citation for published version (APA):

Lorentzen, E., \& Durst-Andersen, P. (2015). The Syntax and Semantics of Russian Non-Sentence Adverbials.

Scando-Slavica, 61(2), 221-260. https://doi.org/10.1080/00806765.2015.1109190 


\title{
The Syntax and Semantics of Russian Non-Sentence Adverbials
}

\begin{abstract}
For the first time non-sentence adverbials in Russian are analyzed in their totality, i.e. from a lexical, syntactic and propositional-semantic point of view. They are classified, defined and interpreted according to four propositional structures identified in Russian: (1) state descriptions and (2) activity descriptions - both created by simplex verbs; (3) event descriptions and (4) process descriptions - both involving complex verbs. All four structures function as statement models and are used to represent semantic paraphrases of utterances in order to be able to show the exact contribution from an adverbial to the meaning conveyed by the entire utterance. The paraphrases allow us to define the domain of an adverbial, its scope and its subdomain possibilities corresponding to its possible meanings. They also allow us to describe lexical differences, i.e. the way a specific adverb differs from other adverbs belonging to the same synonymous group. It appears that members of various synonymous groups differ from one another with respect to subdomain, i.e. their differences in meaning are treated as being reflexes of originally deep syntactic differences. In this connection the so-called entailment structure of all verbs involving an activity description seems to have a special explanatory power.
\end{abstract}

Keywords: Simple and complex propositional structures; perfective and imperfective aspect; domain, scope and subdomain; synonymous groups; entailment structure. 


\section{Introduction}

\subsection{Adverbials in general linguistics}

If we disregard studies of adverbials in connection with aspect and tense (se, for instance, Mittwoch 2001, Musan 2002), the number of books and articles on this item is extremely limited, when we look at publications after 2000 (exceptions are, for instance, Lang et al. 2003, Austin et al. 2004, Hasselgård 2010). It seems to be the case that since Bartsch [1972] 1976 we are not able to find a general work devoted solely to the syntactic category of adverbials. This is a kind of paradox which cannot find a natural solution. It may be connected to two facts. First, it is generally recognized that adverbials comprise a heterogeneous set of lexical and semantic classes and therefore challenge any linguistic theory. Second, traditionally, the adverbial is defined negatively, i.e. everything that is not a subject, a predicate, a direct object, an indirect object, an oblique object or a prepositional object (prepositional phrase) is considered to be an adverbial (see, e.g., Corver and Delfitto 2000, Maienborn and Schäfer 2011). This vague characterization makes it extremely difficult to treat adverbials in any linguistic theory, but more specifically in formal semantics - there seems to be no natural place for them. Although the lack of an exact definition of the adverbial is unsatisfactory, it seems, however, understandable in view of the fact that its syntactic and semantic range is considerably larger than all other syntactic functions. Moreover, the function of adverbials may be expressed by adverbs, noun phrases, prepositional phrases, verb phrases and adverb phrases that all share the semantic function of modifying the sentence one way or the other. In the following we shall use the term 'adverb' when referring specifically to word class and the term 'adverbial' when referring to the particular semanticsyntactic function which is the main subject of this paper.

\subsection{Adverbials in Russian linguistics}


In Russian traditional reference grammars (school grammars), the adverbial (Rus. обстоятельство, cf. Eng. adjunct) is treated as an optional part of a sentence which is mainly used to modify its predicate. Moreover, it is usually mentioned that it can also be used to modify other parts of a sentence. It is further noted that adverbials can be expressed by different parts of speech and phrases which are freely connected with the sentence element they modify and which can be identified by an "adverb-question" (when, where, how, etc.) corresponding to their semantic behaviour as adverbials of time, place, manner, etc. Adverbials are thus categorized in terms of their syntactico-semantic function, but there seems to be no clear-cut distinction between обстоятельство (adverbial) and дополнение (complement) (see, e.g., Šeljakin 1993, Litnevskaja 2006, Voskresenskaja et al. 2013).

In modern Russian linguistics, there are two main approaches to the description of Russian adverbials. The first one is inspired by N. Ju. Švedova $(1964 ; 1968)$ and has been adopted in Švedova et al. 1980 and later university grammars (see, e.g., Belošapkova et al. [1981] 1997, Babajceva and Maksimov [1981] 1987, Švedova, Lopatin et al. [1989] 2002, Valgina [1973] 2003, Sirotinina [1980] 2006, Evseeva et al. 2007, Lekant et al. [2013] 2015). They have abandoned the traditional theory of parts of a sentence in favour of a new one, based on the idea that a simple sentence consists of a predicative nucleus ('предикативный минимум') and a nominative nucleus ('номинативный минимум'). In that way, all other sentence elements are defined according to their obligatory/non-obligatory occurrence/non-occurrence and according to their function with respect to these nuclei. What we call adverbials enter into two major categories - constitutive predicate modifiers (e.g., В юности часто стремятся кому-нибудь подражать 'When you are young, you often try to copy somebody's style'; Он плохо себя чувствовал 'He felt unwell') and non-constitutive predicate modifiers (e.g., Они допоздна 
дружно работали в саду 'They worked in the garden as a team till late at night'). The latter fall into two classes - qualifying predicate modifiers (Работали дружно) and situational predicate modifiers, or so-called determinants (Допоздна работали в саду). Determinants are said to modify the whole sentence and not the predicate alone, as it is the case with qualifying predicate modifiers (Belošapkova et al. [1981] 1997, 794-795). It appears, however, that the proponents of the theory have difficulty in agreeing on the difference between determinants and modifiers as well as between different types of modifiers.

The other approach which can be traced back to L. Tesnière (Tesnière 1959) categorizes various elements of the sentence dependent on the verb as actants or circonstants which differ from each other in that actants fill the active syntactic valence of a verb that corresponds to some semantic valence, while circonstants fill the active syntactic valence of a verb that does not correspond to any semantic valence. Adverbials are normally treated as circonstants, but they appear to be able to function as both actants and circonstants, and the problem of differentiating these functions and description of the numerous cases in-between has been continuously under debate (see, e.g., Apresjan 1974; 2006; 2010, Mel'čuk 1974; 2015, Plungjan and Rachilina 1990, Boguslavskij 1996; 2008, Iordanskaja and Mel'čuk 1996, Chrakovskij 1998; 2012, Padučeva 1999; 2004, Kobozeva 2000, Testelets 2001, and references therein).

In spite of the notable results achieved within syntax and lexical semantics by the scholars representing the two approaches none of them has provided a fully satisfactory analysis and description of Russian adverbials as an integrated system in which all parameters - lexical, syntactic, propositional-semantic and pragmatic - are taken into account consistently and systematically without being intermingled at one of the levels mentioned.

\subsection{Requirements for a grammar of adverbials}


Typically adverbials function as adjuncts, i.e. non-complements which do not occupy an obligatory position in the sentence: ${ }^{1}$

(1) a. I am very tired. Nevertheless, I will stay up till late at night.

b. Strictly speaking, he should have returned home.

c. He told me about his trip at home.

The Anglo-Saxon approach distinguishes three classes with various subclasses (Greenbaum 1969, Quirk et al. 1985, Swan 1988). In (1a) the adverb nevertheless functions as a conjunct, i.e. it relates one sentence to another sentence. In (1b) strictly speaking functions as a disjunct, i.e. it does not serve an internal sentence function, but an external one without relating to a previous sentence. Although the adverbials in (1a) and (1b) have distinct semantic and pragmatic functions, they are united syntactically by both being external to the sentence itself. For that reason we shall subsume conjuncts and disjuncts under the notion of sentence adverbials in contrast to adjuncts (cf. at home in 1c), which are non-complements, but have an internal sentence function in that they determine the predicate. We shall call adverbials of this type nonsentence adverbials (constituent adverbials) which will be the main subject of this paper (for an analysis of Russian sentence adverbials, see Durst-Andersen and Lorentzen 2015). In order to be able to find differences in meaning and use within the heterogeneous class of non-sentence adverbials in Russian we need a broad theory with several partial theories. The requirements for a semantico-syntactically based grammar of adverbials can be reduced to the following:

- It must include a theory of propositional structures forming a certain paradigm to be able to explain, for instance, why some adverbs are used only with perfective verbs and

\footnotetext{
${ }^{1}$ In Russian this function may be represented by adverbs (наречия), particles (частицы), modal words (модальные слова), parenthetical words and expressions (вводные слова и выражения), oblique noun phrases (формы косвенного падежа существительного), prepositional phrases (предложные конструкции), adverbial participles (деепричастия) and adverbial clauses (обстоятельственные придаточные предложения).
} 
others only with imperfective ones;

- It must include a theory of the syntagmatic structure of an utterance to be able to define various domain and scope possibilities;

- It must include a metalanguage that can be used to paraphrase any utterance according to specific choice within the paradigm involving a specific syntagmatic structure.

Let us start with the most fundamental question, i.e. the possible number of propositional structures and their relation to the notion of sentence, and later return to the question of domain and scope. The question of paraphrases will automatically be touched upon when examining the propositional structures.

\section{The four propositional structures}

The number of possible propositional structures can in fact be limited to four in Russian. The four structures are equally divided among the two major verb classes, viz. simplex verbs that comprise imperfective state and activity verbs (as well as all procedural verbs derived from them), and complex verbs that comprise so-called purely aspectual pairs, i.e. those imperfective and perfective verbs which together name the concept of an action (cf. Durst-Andersen 1992; 1994).

\subsection{The two simple structures}

All simplex verbs create a simple propositional structure, as they involve only a single groundproposition, i.e. a proposition that is assertable or deniable in a finite form (cf. below). State verbs involve a state description, named $q$, which, depending on specific verb type membership, may comprise a description of location, possession, experience or quality. Let us take an example involving a location-based state verb with an adverbial as a complement (valence-based 
theories would here avoid the term 'adverbial' because в спортивном зале is an obligatory part of the valence scheme of находиться):

(2) Они находятся в спортивном зале. 'They are in the gym.'

All location-based state verbs can be said to conform to the following paraphrase model:

(2') (X EXISTS ON LOCATION).

Since в спортивном зале specifies the location itself, the adverbial appears to be a locative adverbial.

Similarly, all activity verbs create a simple propositional structure, i.e. they create a single ground-proposition, named $p$, which comprises an activity description that can be asserted or denied. But, due to the fact that all activities in reality are performed against the background of a state, activity descriptions always entail a certain state description $q$ (this means that when the activity description $p$ is true, the state description $q$ is necessarily also true; when the activity description $p$ is false, the state description $q$ is true or false). Let us take a location-based activity verb as an illustrative example:

(3) Они тренируются в спортивном зале. 'They are doing exercises in the gym.'

In the case of (3) the description of some physical activity entails a description of a location, viz. they exist in the gym. They could not be said to be doing exercises, if this or a similar state did not obtain. As we see, the adverbial в спортивном зале is not part of the activity component itself, but of what we will call the entailment structure. In traditional modern grammars, в спортивном зале in (2) and (3) would be treated identically, i.e. as an adverbial that determines the predicate. Strictly speaking, this is only true of (2), but not of (3): here the subject они and в спортивном зале establish a secondary predication (cf. Jespersen 1924) in which в спортивном зале is an adverbial. In that way it is possible to account for the difference between 
Они находятся where the lack of в спортивном зале makes it ungrammatical and Они тренируются where the lack of в спортивном зале seems to be sanctioned by pragmatic rules, i.e. communication rules.

We shall argue that all location-based activity verbs conform to the following paraphrase model, where [ ] marks the entailment structure and ( ) marks the pure propositional structure:

\section{(3') [X EXISTS ON LOCATION] (X PRODUCES AN ACTIVITY).}

Note that if we say Они не тренируются в спортивном зале 'They are not doing exercises in the gym', it may be the case that they are located in the gym ( $q$ is true) or it may be the case that they are not located in the gym ( $\mathrm{q}$ is false). This is exactly what differentiates a logical entailment from a logical presupposition (i.e. q would always be true) (Durst-Andersen 1992, 100-102; 2011, 304; for further discussion, see McCawley [1981] 1993, 326ff, Zvegincev 1976, 207ff, Padučeva 1977; 2011). We would like to turn the reader's attention to the entailment structure which is not only found in activity verbs, but in all verbs involving an activity description. The existence of such a description has never been noticed, although it appears to have a special explanatory power (cf. below).

\subsection{The two complex structures}

The last two propositional structures are complex, because they involve two ground-propositions which together create an action description. An action, which is defined as an activity related to a state by telicity, has no exact counterpart in reality - in the same sense that a human being has no exact counterpart: it will either be a male or a female variety. In other words, an action is a construct that functions as the collective concept of two different complex situation types in reality: (1) an event, i.e. a state caused by an activity, and (2) a process, i.e. an activity which has a state as its purpose. An action description will always manifest itself either as a description 
of an event or as a description of a process if the action verb occurs in a finite form which gives a sentence access to the real world. In Russian the choice between an event description and a process description is connected to the category of aspect. The perfective action verb creates a complex propositional structure where the state description $q$ is asserted and the activity description $p$ is presupposed, and in that way it presents an action as an event, i.e. as a state caused by an activity:

(4) Аня доплыла до берега. 'Anja swam and reached the coast.'

The perfective action verb доплыть presents the action "X (=ANJA) BRING Y (=ANJA) TO Z (=COAST)" as an event by asserting the state description ANJA EXISTS AT THE COAST and by presupposing the activity description ANJA PRODUCED A SWIMMING ACTIVITY which, as any activity description, logically entails another $q$, in this case ANJA EXISTED IN WATER. In that way we get a propositional structure where the logical relation between the activity description and the state description mirrors a CAUSE-EFFECT relationship between the real activity situation and the real state situation. All perfective location-based action verbs conform to the following paraphrase model:

(4') [X EXISTS ON LOCATION 1$]$ (X PRODUCES AN ACTIVITY WHICH IS SUFFICIENT FOR THE FACT THAT X EXISTS ON LOCATION 2 ).

The perfective paraphrase model consists of the following components forming a certain syntagmatic structure:

- The entailment structure:

- The activity description $p$ :

- The intermediate description:

- The state description $q$ :
X EXISTS ON LOCATION . $_{1}$ X PRODUCES AN ACTIVITY. THE ACTIVITY IS SUFFICIENT. X EXISTS ON LOCATION 2 . 
Let us for illustrative purposes replace the perfective verb in (4) by the corresponding imperfective action verb:

(5) [В ЭТО ВРЕМЯ] Аня доплывала до берега. 'Anja was swimming towards the coast and was about to reach it.'

The imperfective verb presents the action "X (=ANJA) BRING Y (=ANJA) TO Z (=COAST)" as a process by asserting the activity description $p$ and by treating the state description $q$ as a standard implicature, i.e. the hearer himself has to find out whether the state description $q$ is true or false. In that way we get a propositional structure which shows that the real state situation referred to is the goal of the real activity situation. All imperfective location-based action verbs conform to the following paraphrase model:

(5') [X EXISTS ON LOCATION 1$]$ (X PRODUCES AN ACTIVITY WITH THE INTENTION THAT IT BE SUFFICIENT FOR THE FACT THAT X EXISTS ON $\mathrm{LOCATION}_{2}$ ).

As appears from the paraphrases in $\left(4^{\prime}\right)$ and $\left(5^{\prime}\right)$, both involve an entailment structure, an activity description and a state description. The only difference between the two complex propositional structures, i.e. the perfective and the imperfective ones, is to be found in the intermediate description between $p$ and $q$ : the perfective structure has a causation description as intermediate description (THE ACTIVITY IS SUFFICIENT) which means at the propositional level that $q$ is asserted and $p$ is presupposed, whereas the imperfective one has a finality description as intermediate description (WITH THE INTENTION THAT THE ACTIVITY BE SUFFICIENT). In general, this means at the propositional level that $p$ is asserted and $q$ is either true or false. Because $q$ is named by the imperfective action verb, but not asserted, the question of whether $q$ is true or false must be solved by the hearer himself: If the hearer assigns true to $q$, we get a 
characterization of $\mathrm{X}$, i.e. $\mathrm{X}$ has the quality of having produced an action, for instance $\mathrm{OH}_{\mathrm{H}}$ приходил ко мне вчера вечером 'He visited me last night'; if the hearer assigns false to $q$, then we get a description of an ongoing process, the principal meaning of the imperfective aspect, cf. (5) and (5'). In other words, this job is placed with the hearer due to the fact that the imperfective aspect does not involve any specific truth value assignment at all to the state description. Note that in connection with negation the state description is treated as being neither true nor false, which means that the question of $q$ 's truth or falsity is completely irrelevant, i.e. it will never pop up in the hearer's mind, for instance, Он не приходил ко мне вчера вечером 'Не wasn't at my place last night'.

The different truth value assignments in the perfective and the imperfective propositional structures are responsible for the fact that certain adverbs act transitively (in the logical sense of the word) in the perfective structure, cf. Вчера он ее уговорил пойти в кино 'Yesterday he persuaded her to go to the movies' (i.e. if $p$ was true yesterday, then $q$ was also true yesterday), but intransitively (in the logical sense of the word) in the imperfective one, cf. Вчера он ee уговаривал пойти в кино 'Yesterday he tried to persuade her to go to the movies' (i.e. if $p$ was true yesterday, then nothing can be said about $q$ 's being true yesterday). In other words, scope understood as radius of operation and domain understood as place of operation are closely connected in some cases, as we shall also see in section 3 (for different approaches to the notion of scope in Russian linguistics, see Boguslavskij 1996, Filipenko 1998; 2003, Rudnickaja 1994).

In section 6 and 7 we shall examine adverbials that differ in meaning when they occur with the perfective and imperfective forms of complex verbs. In this connection, it should be noted that many of the differences to be mentioned have already been observed by Russian aspectologists (see, for instance, Glovinskaja 1982, Bondarko 1983 and others), but they are 
described in a non-uniform and opaque way. Our way of describing the differences in meaning is meant to be completely uniform and transparent.

\section{Domain, subdomain, and scope}

The four propositional structures introduced above have all in common that they occur at the place that in traditional paraphrases is called "p" (cf. Lyons 1977). It goes without saying that if one puts an equality sign between sentence and proposition, the problems of domain and scope become even more evident, because the possibilities of showing differences in domain and scope are extremely limited. Admittedly, we need not pay attention to the propositional structures when dealing with sentence adverbials, because this major class of adverbials is external to the structures themselves. But for all non-sentence adverbials it is of vital importance to distinguish different propositional structures.

First, there are adverbials (e.g., вдруг 'suddenly', иногда 'sometimes', все время 'all the time', and others) which apply to either the perfective or the imperfective structure because of their lexical meaning. Secondly, some of the adverbials which apply to both complex structures may function differently and convey different meanings when used. Grammars which do not distinguish different propositional structures are not capable of describing and explaining these phenomena, although they may have been observed. Moreover, it is crucial to point out that the four examined propositional structures not only constitute four different domains, but simultaneously involve several scope possibilities depending on what subdomain a given adverbial enters, i.e. its specific sphere of operation within a domain. This becomes particularly evident when speaking of the perfective statement model (one domain out of four possibilities) which includes four different subdomains and therefore, in principle, four different scope possibilities: (1) the entailment structure, (2) the activity description $p$, (3) the causation 
(intermediate) description, and (4) the state description $q$. Let us take the negation particle не as an illustrative example.

The negation particle не may, of course, be applied to all four simple and complex propositional structures, but when applied to the perfective statement model, it will operate on the causation description and have this as its subdomain. Due to the transitive nature of не, the state description $q$ is also negated (cf. Иван не продал старую машину 'Ivan didn't sell his old car'). In other words, not only the causation description, but also the state description is within its scope. In connection with the imperfective statement model не will operate on the activity description and have this as its subdomain (cf. Иван не продавал старую машину 'Ivan didn't try to sell his old car'). This will affect all the following descriptions, but not the preceding one, i.e. the entailment structure, viz. Ivan still possesses the old car.

It goes without saying that not all adverbials are capable of modifying all the abovementioned descriptions. The lexical meaning of a particular adverbial may be disharmonic with the lexical meaning of a particular verb or its aspectual value and therefore yield an ungrammatical utterance in Russian, cf. *Вдруг пахло бензином 'Suddenly there was a smell of gas'. Such utterances might seem perfectly natural to a foreign speaker, if his or her own mother tongue does not distinguish between an activity and a change from a non-activity to an activity as Russian has to do because of its aspectual system. In that way, we can say that there exists a certain harmony between 'suddenly' and the Russian perfective aspect, cf. Вдруг запахло бензином: both involve change of state.

Non-sentence adverbials operate within the simple or complex propositional structures examined above. This means that they may have a description of either a state, an activity, a process or an event as their domain. The notion of domain is paradigmatically defined, i.e. there 
is an obligatory choice among the four propositional structures. Normally, this would - and should, strictly speaking - exclude the notion of scope which is syntagmatically defined. But due to the fact that, for instance, an event description (e.g., Они уехали в Париж на поезде 'Тhеу went to Paris by train') is composed of four interrelated subdescriptions, viz. (1) the entailment structure (They were on a train as they...), (2) the activity description (They produced an activity), (3) the causation description (The activity was sufficient), and (4) the state description (They exist in Paris), a non-sentence adverbial may operate on any of these four subdomains whereby, in principle, we get four scope potentials if the adverbial is transitive in nature. By dividing a sentence into several interrelated propositions we get a possibility to explain the interrelationship between position and scope of an adverbial in a natural way.

The notion of scope in connection with non-sentence adverbials is different from the notion of scope in connection with sentence adverbials (for more about this, see Durst-Andersen \& Lorentzen 2015). In the latter case we are dealing with a semantic notion. For instance, as a sentence adverbial, серьёзно 'seriously speaking' (cf. Серьёзно, он говорил ей об этом много pa3 'Seriously, he told her about it many times') affects not only the component "I hereby say", but also the component "it is true", and because of that it simultaneously affects the propositional content proper - all utterance components and all propositional parts are said to be within its scope. As a non-sentence adverbial having the entailment structure as its subdomain, серьёзно ‘seriously' (cf. Он серьёзно говорил ей об этом много раз 'He seriously told her about it many times') need not range over the remaining subsequent propositional structures. Only adverbials that are transitive in nature may have this long-range effect, and if transitive, the effect will often have the status of an implicature. Adverbials that are intransitive in nature will have a limited sphere of operation, and their influence will be restricted to the specific 
subdomain on which they operate. We shall return to this issue at several places in the following paragraphs, but first we shall have a brief look at adverbials in connection with state verbs, where the notion of scope plays no role since we are concerned with one single proposition.

\section{Adverbials having state descriptions as their domain}

State verbs, including not only the original imperfective verbs such as сидеть 'sit', but also all perfective and imperfective procedural verbs derived from them, such as, for instance, посидеть and посиживать 'sit a little while', просидеть and просиживать 'sit for a period without interruption', and пересидеть and пересиживать 'sit too long', constitute the most simple kind of verbs by creating a state description. As might be predicted, some adverbials are excluded from the possibility of modifying a state description alone. This concerns adverbials which one way or another involve dynamicity and therefore require an activity description (e.g., быстро ‘quickly', медленно 'slowly', намеренно ‘intentionally', нарочно 'deliberately, on purpose', нечаянно 'unintentionally', умело 'skilfully', etc.). Apart from this restricted group, all other adverbials are fully capable of modifying a state description, be that as a temporal adverbial as in (6), as a locative one as in (7), or as a manner adverbial as in (8):

(6) Они долго сидели на диване и молчали. 'They sat on the sofa in silence for a long time.'

(7) Он прожил два года в Москве. 'He has lived in Moscow for two years.'

(8) Занавески висят ровно. 'The curtains are hanging straight.'

Some adverbial participles, all derived from perfective action verbs, have lost their action meaning and are used as absolute constructions, or idioms, to describe a way of being in a certain state. In other words, there is no secondary predication (in the sense of Jespersen's notion of secondary nexus, cf. Jespersen 1924) involved in absolute constructions: 
(9) а. Она сидела в кресле скрестив на груди руки. 'She was sitting on the chair with her arms folded.'

b. Он целый день сидел сложа руки. 'He was sitting idly all day long (lit. with folded hands).'

с. Она сидела на диване поджав под себя ноги. 'She was sitting on the sofa with her legs tucked under her.'

d. Он сидел прямо положив руки на колени. 'He was sitting straight with his hands on his knees.'

When speaking of adjectives which denote a human state of mind (e.g., грустный 'sad', весёлый 'cheerful, gay', радостный 'glad', кислый 'glum', удрученный 'depressed', расстроенный 'out of one's mind, sad', etc.) the adjectival form is normally preferred to the adverbial one in connection with location-based state verbs like стоять 'stand', сидеть 'sit' and лежать 'lie', whereby we get a secondary predication which, interestingly enough, appears to be primary in relation to the position description. If an adverb is chosen, it will often be infelicitous and yield a comic effect as in (10b):

(10) a. Почему ты сидишь такая грустная? 'Why are you looking (lit. sitting) so sad?' b. Почему ты сидишь так грустно? 'Why are you sitting so sadly?'

The word order may, however, affect the grammaticality of the adjectival and the adverbial forms as in the following examples:

(11) а. Нетерпеливый, он потом много раз здесь стоял и ждал. 'Impatient as he was, he would often stand and wait.'

b. Он потом много раз нетерпеливо стоял здесь и ждал. 'Afterwards he would often be (standing and) waiting impatiently.' 
In (11a) with the adjective in front position it would be impossible to exchange it for an adverbial form (presumably because нетерпеливый is coupled to the state description alone, i.e. стоял), and in (11b) with the adverbial in middle position between the subject and the verb it would be equally impossible to exchange it for an adjectival form (presumably because нетерпеливо is coupled to the activity description, i.e. to стоял и ждал en bloc). In other cases, both forms in final position will be equally grammatical and acceptable, but will differ in meaning:

(12) а. Брёвна лежали кривые и потрескавшиеся. 'The logs were (lit. lying) crooked and cracked.'

b. Брёвна лежали криво. 'The logs were lying tilted.'

In (12a) it is stated that the logs themselves are not straight, whereas in (12b) they may be straight, but are stacked in a tilted position.

\section{Adverbials having the entailment structure as their subdomain}

As mentioned at several places in section 2, the entailment structure also involves a state description, but this state description is logically entailed by the activity description. Normally the adverbials which are taken here to modify the entailment structure are in other theoretical frameworks referred to by the notions of subject disjuncts (cf. Greenbaum 1969, Cresswell 1985, Swan 1988) or subject-oriented sentence adverbials (cf. Jackendoff 1972, Nølke 1978, Rudnitskaja 1994, Maienborn and Schäfer 2011). In other words, within these theories they are defined as a specific kind of sentence adverbials. The so-called subject disjuncts (cf. 13b) are considered to have a narrower scope than style disjuncts (cf. 13a), but at the same time to have a broader scope than manner adjuncts (cf. 13c) corresponding to the three traditionally recognized 
syntactic basic positions, viz. initial position, middle (auxiliary) position and final position (cf. Jackendoff 1972):

(13) a. Seriously, he told her about it many times. (= I am serious as I hereby say...)

b. He seriously told her about it many times. (= He was serious as he told...)

c. He told her about it seriously many times. (= He told it in a serious way)

The three English examples can be translated into similar Russian examples without changing word order. In that way the specific and relative position of the adverbial in the three examples can be argued to reflect its scope or subdomain location in a diagrammatical way, i.e. iconically:

(14) а. $\leftarrow$ Серьёзно, он говорил ей об этом много раз. ( $\leftarrow$ points to the speaker)

b. Он $\leftarrow$ серьёзно говорил ей об этом много раз. ( $\leftarrow$ points to the subject)

с. Он говорил ей об этом $\leftarrow$ серьёзно много раз. ( $\leftarrow$ points to the verb phrase)

However, it is important to note that (14b) is, in fact, ambiguous - in other words, it may have the same meaning as $(14 \mathrm{c})$.

This kind of ambiguity cannot be found in English utterances because of the word order Su Verb (Obj) Adv in the case of non-compound forms of verbs (cf. 15b and 16b) ${ }^{2}$ :

(15) а. Он ясно ответил на заданный вопрос.

b. He answered the question clearly.

(16) а. Она правильно поступила в этой ситуации.

b. In this situation she acted correctly.

In the present framework, the so-called subject disjuncts or subject-oriented sentence adverbials (cf. (13b) and (14b)) are not treated as sentence adverbials and could not be because they are taken to modify the entailment structure which is an obligatory part of any VP containing an activity description. In this way it becomes understandable why (14b) is ambiguous. Moreover, it

\footnotetext{
${ }^{2}$ Note that these examples refer solely to syntactic position and have nothing to do with the entailment structure.
} 
reveals some of the fundamental problems when treating one sentence as involving one proposition.

Although серьёзно 'seriously' is said to modify он 'he', it may still be ambiguous because он is in fact not only the Actor and surface subject of the sentence Он серьёзно говорил ей об этом много раз, but он is also carrying a state role in that it functions as the underlying subject of the state description "He was together with her". In the former case oH points to the activity description, i.e. it modifies the Actor's activity, while in the latter case or points to the state description logically entailed by the activity description, i.e. it specifies his mental state when producing the activity. From the point of view of surface syntax серьёзно can be said to relate to either он or говорил as shown by the arrows in (16c):

(16) с. Он $\leftarrow$ серьёзно $\rightarrow$ говорил ей об этом много раз.

The ambiguity is not so easily solved because the two meanings are not mutually exclusive: If the Actor was serious, he probably told it to her in a serious way, and if he told it to her in a serious way, he was probably serious when doing it. As should be evident, серьёзно is highly transitive in nature. As a matter of fact, the hearer may also conclude from hearing (14c) that the words which were seriously produced were experienced by the Recipient to be serious.

Before going into a more detailed description of two groups of adverbials that can modify the entailment structure, we shall look briefly at the adverbial participle form again when used in an absolute construction, i.e. in a construction where the activity description of the action description has vanished:

(17) а. Он ходит по комнате заложив руки за спину. 'He walks around in the room with his hands behind his back.'

b. Она слушает разинув рот. 'She is listening open-mouthed.' 
с. Он работает спустя рукава. 'He works in a slipshod manner' (lit. with his sleeves down).

d. Они бежали сломя голову. 'They were running with breakneck speed.'

е. Он глядел на нее нахмурив брови. 'He looked at her with knitted brows.'

The loss of the action character in these forms of perfective action verbs is conditioned by the grammatical properties of the perfective aspect. Since the perfective verb asserts the state description (and not the activity description), it becomes possible for the adverbial participle construction to turn into an absolute construction only denoting a state - the state the Actor is in when producing the activity mentioned by the main clause verb. In (17a), for instance, it is stated that somebody has his hands behind his back as he produces a walking-around activity. Had the activity not been totally suppressed, it would not have been an absolute construction with the meaning of a manner adverbial, but instead an infinite construction which denotes a secondary action in relation to the primary action referred to by the finite verb (cf. After having put his hands behind his back he...) (cf. the notion of taxis used in Jakobson [1957] 1971). Note that this meaning can be realized in some of the above-mentioned examples, if the clause order is changed by foregrounding the adverbial phrase and if the imperfective construction in the main clause is given a dynamic character, for instance, by using the perfective phaseal verb стал 'he began' (cf. Заложив руки за спину, он стал ходить...). This is not possible in connection with state verbs where there is no action at all and where the question of primary and secondary actions is completely irrelevant.

\subsection{Actor-qualifying adverbials}

All adverbials that modify the entailment structure by assigning the Actor (being also the underlying subject of the state description in the entailment structure) a quality are manner 
adverbs ending in -o which obligatorily occupy the position after the subject of the sentence. Although all activity and action verbs have an entailment structure, i.e. a state description that is logically entailed by the activity description, it is not all of them that are capable of adopting a manner adverbial in their entailment structure. Only those verbs which involve an agentcontrolled activity may attract actor-qualifying adverbials. That is why (18) cannot mean that the manager was strong as he got surprised:

(18) Директор сильно удивился. 'The manager was extremely surprised.'

Moreover, it goes without saying that the lexical meaning of an adverb also plays an essential role. The adverb must include in its lexical meaning the semantic component [+human quality], i.e. the adjective from which the adverb is derived should be able to attract a noun denoting a human being, for instance, он - легкомысленный / честный / серьёзный / разумный / опрометчивый / робкий человек 'He is a careless / honest / serious / reasonable / rash / timid person'. Let us take some illustrative examples involving action verbs, primarily perfective ones:

(19) а. Я легкомысленно ${ }^{3}$ оставил дома все теплые вещи. 'I carelessly left all my warm clothes at home.'

b. Она честно призналась в своей вине. 'She honestly admitted her fault.'

с. Она горячо учила Надю Романову жить своей жизнью. (Petruševskaja) 'She eagerly tried to persuade Nadja Romanova to live her own life.'

d. Она опрометчиво приняла его предложение. 'She rashly accepted his proposal.'

е. Она робко возразила. 'She timidly objected to it.'

If they are paraphrased according to our statement models, we get the following:

\footnotetext{
${ }^{3}$ Note that Rudnickaja 1994 treats this use of legkomyslenno as a sentence adverbial.
} 
(19') a. I was careless as I produced an activity that was sufficient for the fact that all my warm clothes exist at home.

b. She was honest as she produced an activity that was sufficient for the fact that her guiltiness exists for the hearers.

c. She was eager as she produced an activity with the intention that it be sufficient for the fact that Nadja Romanova lives her own life.

d. She was rash as she produced an activity that was sufficient for the fact that there exists an agreement between them.

e. She was timid as she produced an activity that was sufficient for the fact that she is against (what he said).

In principle, all the above-mentioned examples are ambiguous, for instance (19b), which in its second meaning can be paraphrased as follows (see 20'):

(20') She produced an honest activity that was sufficient for the fact that her guiltiness exists for the hearers.

It must be emphasized that there is a significant difference between these two readings. In (19b') the female person is claimed to be honest when she utters "I am guilty". She might have said Честно говоря, я виновата. 'Honestly, I am guilty'. In (20') we are not told explicitly that she was honest when she uttered her words, but instead that her words were produced in an honest way. In other words, she must have said more than Я виновата. This could very well open up for a third reading, namely that her words were experienced by the recipients to be honest. This reading becomes more explicitly expressed when честно is placed in the rightmost position:

(21) Она призналась в своей вине честно. 'She admitted her fault in an honest way.' 
This is in fact a good example of the difference between subdomain and scope. When честно has the entailment structure as its subdomain, its scope is, properly speaking, restricted to this very subdomain. It may range over it thereby affecting the activity component and the state component of an action verb, but when it does, it is a conversational implicature: if somebody was honest, then he or she must have produced some words in an honest way, and people having heard them must have had the impression that they were honestly meant, etc. As we realize, we easily run around in circles.

In connection with activity verbs the difference in meaning between a manner adverbial in middle position and one in final position is fairly great as is evident from the following example:

(22) а. Она хорошо плавает. 'She is good at swimming.'

b. Она (всегда) плавает хорошо. 'She swims/is (always) swimming well.'

(22a) in its default reading can only be understood as a categorization of the person in question, i.e. she is a good swimmer. (22b) in its default reading denotes a situation or person characterization (only the determinate verbs of motion can denote a situation description, cf. Она плывет хорошо). (22b) is ambiguous from the point of view of English (cf. the two translations): it either characterizes the way in which the person swims or presents the activity referred to as a picture description (cf. I can see she is swimming well).

Because of their lexical meaning some adverbials cannot range over their own subdomain and are always placed in the entailment structure by the hearer:

(23) Он внимательно прочитал стихотворение. 'He read the poem with attention.'

(23') He was attentive in detail as he produced an activity that was sufficient for the fact that the poem exists for him as an experience.

(24) Он неловко сел. 'He sat down clumsily.' 
(24') He was uncomfortable as he produced an activity that was sufficient for the fact that he exists in a sitting position.

(25) Она умело отремонтировала одежду. 'She repaired the clothes skilfully.'

(25') She was skilful as she produced an activity that was sufficient for the fact that the clothes are in good condition.

(26) Он умышленно умолчал о самом главном. 'He deliberately left out the most important part.'

(26') He was fully aware of what he intended to do as he produced an activity that was sufficient for the fact that the most important part did not exist on world-location.

Later on we will attempt to demonstrate that adverbs which constitute so-called synonymous groups may differ from one another with respect to natural subdomain location.

\subsection{Actor-localizing and Undergoer-localizing adverbials}

Two subtypes of localizing adverbials have to be distinguished although they have the same formal means, i.e. they are expressed by a prepositional phrase.

Actor-localizing adverbials relate to the subject of the sentence:

(27) а. Студенты ехали в университет на метро. 'The students were travelling to university by subway.'

b. Ребенок прыгает в воде. 'The child is jumping in the water.'

с. Родители уехали на вокзал на такси. 'The parents went to the station in a cab.'

(27') a. The students were in a train as they were on their way to the university.

b. The child is in water as he produces jumping-activity.

c. The parents were in a taxi as they produced an activity that was sufficient for the fact that they exist at the railway station. 
The paraphrases of (27a) and (27b), which are both activity descriptions, show that the Actor is in the location as long as the activity goes on. After that it is for the hearer to decide. In the case of (27c), which is an event description, the Actor's location is gone as soon as the new state appears, i.e. when the parents reached the railway station, they left the cab - this is the normal reading. The shift from being in the cab to being outside the cab is in fact necessary in order to be able to assert the state description "They exist at the railway station". Without this shift of location the story could never continue.

Undergoer-localizing adverbials relate to what at the surface level appears to be a direct object, but which at a deeper level appears to have two different functions, i.e. that of an internal object which corresponds to the semantic role of Undergoer (in this function it is underlying subject $_{1}$ of a state description in the entailment structure) and that of direct object which corresponds to the Direct Patient Role (in this function it is underlying subject 2 in the independent state description of an action verb):

(28) а. Профессор рассмотрел препарат под микроскопом. 'The professor examined the sample under the microscope.'

b. Нашу лабораторию целиком перевели в новый институт. 'The whole laboratory was moved to a new institute.'

(28') a. The sample 1 was under the microscope as the professor produced an activity that was sufficient for the fact that the sample 2 exists for him as an experience.

b. The laboratory $y_{1}$ was complete as one produced an activity that was sufficient for the fact that the laboratory 2 exists at a new institute.

In other words, just as професcop in (28a) has two semantic roles, i.e. that of an Agent and that of an Experiencer, the role of препарат is also twofold. On the one hand, it is the underlying 
subject in the entailment structure where под микроскопом is an adverbial (i.e. "The sample exists under the microscope, as the professor..."), and, on the other hand, it is the underlying subject in the state description (asserted by the perfective verb) where под микроскопом has nо place at all (i.e. "The sample exists for the professor as a visual experience"). The same holds true of лабораторию 'laboratory' and целиком 'in total' in (28b) - the latter is opposed to полностью 'fully' which normally has the state description as its subdomain (cf. Они полностью выполнили программу 'They carried out the program in full') (For a detailed description of polnost 'ju and celikom, see Grigor'eva 2004).

The entire analysis is attractive because it makes a whole set of apparently opaque constructions in Russian quite transparent. We now have the means to explain and describe why Russians say Профессор рассматривает препарат под микроскопом (the sample exists under the microscope as he produces the activity) and how it differs from the alternative Профессор рассматривает препарат в микроскоп: here he is viewed as a person who performs an activity, the direction of which runs through the microscope with the purpose of examining the sample.

Let us take a couple of expressions, all with Actor-qualifying adverbials, which are difficult to understand and to use for the foreign learner because they are felt to be opaque (there are no exact correspondents in their mother tongue):

(29) а. Они гуляли под дождем. 'They walked in the rain.'

b. Она читает в очках. 'She reads/is reading with her glasses on.'

с. Он ходит с палкой. 'He walks with a stick.'

We argue that the Russian way of describing various states (e.g., Они сидели под дождем 'lit. They were sitting under the rain (i.e. in the rain)', Она в очках 'lit. She is in glasses (i.e. She 
wears glasses)', Он с палкой 'lit. He is (together) with a stick' shows on the surface when these descriptions co-occur with activity and action verbs - here they are used to localize the Actor or the Undergoer of the given activity or action. In this way Russian seems to provide especially convincing evidence for the fact that any activity description necessarily implies a state description, i.e. all verbs involving an activity description have an entailment structure.

6. Adverbials having activity descriptions as their subdomain Activity verbs and action verbs which involve an activity description can admit adverbials which, one way or the other, modify the activity description. It concerns (1) manner adverbials like быстро 'quickly', медленно 'slowly', подробно 'in detail', удачно 'successfully, well', намеренно 'intentionally', глупо 'stupidly', хорошо 'good, well', плохо 'badly', (2) durative adverbials like долго 'long, (for) a long time', три часа 'three hours', всё время 'all the time', and (3) adverbials in the instrumental case like карандашом 'with a pencil', ножом 'with a knife', etc. Some of them, for instance, подробно 'in detail', удачно 'successfully, well', намеренно 'intentionally, deliberately' enter into a specific group because they lack the ability to modify the finality/causation description as well as the state description of action verbs. In other words, they have only a single possible subdomain, namely the activity description itself. As we see, they are combined with both imperfective and perfective verbs:

(30) а. Он подробно описывал / описал свои приключения. 'He described his adventures in detail.'

b. Она намеренно скрывала / скрыла свой возраст. 'She deliberately concealed her age.'

с. Она удачно выступала / выступила в новом амплуа. 'She performed very well in her new role.' 
In all three cases, the meaning can be reduced to the following: Somebody produced a detailed / intentional / excellent activity - whether the state did or did not obtain is irrelevant for the use of the adverbials. That is to say when one says Он подробно описал (pf) свои приключения, the speaker asserts that the adventures exist for the hearer as an experience, but he does not assert that they exist in detail. The hearer may conclude from hearing this utterance that they do so because of the detailed character of the activity itself, but it has nothing to do with the adverbial. In short, these adverbials are not transitive in nature.

However, some manner adverbials are highly transitive in nature because of their lexical meaning which naturally attracts a special kind of action verbs, i.e. those referring to actions where there is a natural relationship between the way in which the activity is produced and the consequent state itself:

(31) а. Она громко назвала фамилию студента. 'She loudly called the student's surname.’

b. Учитель понятно объяснил урок. 'The teacher explained the lesson clearly.

с. Грузчики аккуратно упаковали все вещи в коробки. 'The movers very carefully packed all the things in boxes.'

Although, sensu stricto, the adverbials in (31) modify the activity description, they, nevertheless, act transitively whereby they automatically extend their scope. The consequence is that they range over the causation description and reach the state description. This long range effect does not only require a specific type of manner adverbials, but also, as noted above, a specific type of action verbs: the verb must name a complex situation where in all normal worlds there is a certain kind of symmetry between the activity and the consequent state: the higher the speaker shouts, the higher the shout sounds for the hearer. 
Other manner adverbials such as быстро 'quickly', медленно 'slowly', хорошо 'good, well', плохо 'badly', and several others co-occur with both perfective and imperfective verbs, but only in the latter case they modify the activity description due to the assertive properties of the imperfective aspect:

(32) а. Он быстро продвигался по службе. 'He advanced rapidly in his job.'

b. Она медленно вставала с кровати. 'She was rising slowly from her bed.'

с. Вы хорошо отдыхали в этом году? 'Did you have a nice holiday this year?'

(32') a. He produced a rapid activity with the intention that it be sufficient for the fact that he has a higher position.

b. She produced a slow activity with the intention that it be sufficient for the fact that she is standing on her feet.

c. I hereby ask you to commit yourself to the truth or falsity of the following statement: "You produced good activities during the holiday".

As we can see, the last example is completely impossible to translate word by word; only by giving paraphrases it was possible to show the exact meaning (cf. 32c and 32c').

Adverbials like постепенно 'gradually', мало-помалу 'little by little', еле-еле 'scarcely, barely', едва 'hardly, only with difficulty', с трудом 'with difficulty', and others described as a specific group in Apresjan 1997 (see also Apresjan 2004) operate on the activity description when speaking of imperfective verbs, but when used with perfective verbs they automatically modify the causation description (see (33) compared to (37)):

(33) а. Молодежь постепенно вытесняла старшее поколение. 'The young generation was gradually supplanting the older one.' 
b. После полудня мы еле-еле тащили ноги. (Arsen'ev) 'After noon we could barely drag our feet.'

с. Печь едва горит. 'The oven is hardly working.'

(33') a. The young generation gradually produced an activity with the intention that it be sufficient for the fact that the older generation is out of the way.

b. After noon we scarcely produced walking activity.

c. The oven hardly produces a burning activity.

Durative adverbials can only be used together with simplex verbs (be they imperfective verbs or perfective procedural verbs) or with imperfective complex verbs:

(34) а. Дети долго играли во дворе. 'The children played in the yard for a long time.'

b. Дети катались на коньках три часа. 'The children skated for three hours.'

с. Дома дети все время делают домашние задания. 'The children are always doing their homework when they are at home.'

(34') a. The children produced a long lasting playing-activity in the yard.

b. The children produced three hours' skating activity.

c. At home the children produce a constant homework activity.

In all paraphrases the adverbial appears to be an attribute of the activity, i.e. it modifies the activity as an attribute modifies a noun. The use of the instrumental case in its main adverbial function is not an exception to this apparently general rule:

(35) a. Она пишет карандашом. 'She is writing with a pencil.'

b. Она написала весь роман карандашом. 'She has written the entire novel with a pencil.' 
In both cases the speaker says that she produces / produced a pencil-writing activity. Note, however, that in (35b) the hearer automatically transfers the activity-defining adverbial to the state description itself simply because the marks from the pencil exist on all the sheets (The entire novel was written in pencil).

It is crucial to note that our solution to adverbials modifying an activity seems to be intuitive and attractive at the same time. We argue and demonstrate that this kind of adverbials comes from what appears to be an adnominal modifier at a deeper syntactic level (cf. all the paraphrases). In that way we go a little bit further than Davidson (1967) who treated adverbial modifiers on a par with adnominal modifiers thereby acknowledging their fundamental similarities.

\section{Adverbials having causation or finality descriptions as their subdomain}

If we disregard adverbials which are only used to modify the activity description (cf. above), it can be argued that manner adverbials tend to behave according to the assertive properties of the perfective and imperfective aspects. Since an imperfective verb asserts an activity description, it will normally force an adverbial to operate on this subdomain, and since a perfective verb asserts a state description, it will normally force the adverbial to operate either on the intermediate causation description, i.e. the description which is responsible for the truth of the state description, or on the state description itself. Only when an adverbial carries a specific lexical meaning, it may force its way through to another position than the one normally required by the perfective and imperfective verbs.

Let us now look at examples which are parallel to (32) and (33) presented above (for further information, see Prokopovič 1982, 245ff, Bondarko 1983, 116ff):

(36) а. Он быстро продвинулся по службе. 'He quickly got promoted.' 
b. Она медленно встала с постели. 'She got up slowly from her bed.'

с. Вы хорошо провели отпуск? 'Did you have a nice holiday?'

(36') a. He produced an activity that was quickly sufficient for the fact that he has a higher position.

b. She produced an activity that was slowly sufficient for the fact that she is in on her feet.

c. I hereby ask you to commit yourself to the truth or falsity of the following statement: "The holiday exists for you as a good experience".

This also applies to adverbials like постепенно 'gradually', мало-помалу 'little by little', еле(еле) 'scarcely, barely', едва 'hardly, only with difficulty', насилу 'hardly', с трудом 'with difficulty', and others. In connection with the perfective aspect they cannot but operate on the causation description:

(37) а. Молодежь постепенно вытеснила старшее поколение. 'The young generation gradually supplanted the older one.'

b. Он еле-еле спасся. 'He barely escaped.'

с. А я тебя тоже насилу узнал (Tolstoj). 'I hardly knew you too.'

d. Она едва удержалась от смеха. 'She barely kept herself from laughing.'

е. Он с трудом решил задачу. 'He solved the problem with difficulty.'

(37') a. The young generation produced an activity that was gradually sufficient for the fact that the older generation is out of the way.

b. He produced an activity that only with great difficulty was sufficient for the fact that he is alive. 
c. And I also produced an activity that only with great difficulty was sufficient for the fact that you exist for me as yourself.

d. She produced an activity that only with difficulty was sufficient for the fact that she is calm.

e. He produced an activity that with difficulty was sufficient for the fact that the right answer exists on world-location.

As shown in Apresjan 1997 the lexical differences in meaning and use between the adverbials from (b) to (d) are tiny and sophisticated, and for that reason they do not appear from the paraphrases. The adverbial с трудом, for instance, presupposes an activity which is agentcontrolled and difficult in itself - therefore it cannot occur with a negated verb - but, unlike, for instance еле 'scarcely, barely' and едва 'hardly, only with difficulty', it does not require ostensiveness, i.e. the fact that it was difficult need not be visible to others. The adverbial насилу 'hardly' differs from all the other members of the group by implying a positive attitude of the speaker.

Time adverbials which co-occur with perfective verbs are different from durative adverbials which co-occur with imperfective verbs simply because they operate on another subdomain:

(38) а. Он написал рапорт за три часа. 'He wrote the report in three hours.'

b. Она управилась со всеми делами в два дня. 'She accomplished everything in two days.'

$\left(38^{\prime}\right)$ a. He produced an activity that after three hours was sufficient for the fact that the report exists on world-location. 
b. She produced an activity that in two days was sufficient for the fact that the result of her activity is on hand.

A small number of adverbials can occur only with perfective action verbs when they are used as non-sentence adverbials. This concerns, for instance, случайно 'at random, by accident' (cf. Apresjan 1980, 79ff) (Note that in Apresjan's example involving the imperfective aspect Иван случайно решал ту же самую задачу, что и Борис, it is used as a sentence adverbial):

(39) a. *Ученик случайно решал задачу. ‘*The pupil tried by accident to solve the problem.'

b. Ученик случайно решил задачу. 'The pupil solved the problem by accident.'

$\left(399^{\prime}\right)$ a. *The pupil produced a random activity with the intention that ...

b. The pupil produced an activity that was accidentally sufficient for the fact that the right answer exists on world-location.

The point is that in connection with a goal-directed activity it is absurd to claim that the activity was produced accidentally. It makes sense, however, to claim that somebody produced an activity that had a desirable, but unwarranted consequence.

Only few adverbials can operate on the intermediate description (i.e. the finality or the causation description) in connection with both perfective and imperfective verbs:

(40) а. Он нарочно звонит ей домой. 'He deliberately calls her at home.'

b. Он нарочно позвонил ей домой. 'He deliberately called her at home.'

$\left(40^{\prime}\right)$ a. He produces an activity with the intention that it be deliberately sufficient for the fact that he is in contact with her by phone.

b. He produced an activity that was deliberately sufficient for the fact that he is in contact with her by phone. 
Later both случайно 'at random, by accident' and нарочно 'deliberately' will be contrasted with the adverbs which are close to them in meaning.

\section{Adverbials modifying state descriptions of action verbs}

The majority of adverbials which can be used to modify the state description are found only in connection with perfective verbs due to their grammatical meaning:

(41) а. Он наконец вырос. 'He finally grew up.'

b. Она тепло оделась. 'She dressed in warm clothes.'

с. Она красиво вышила скатерть. 'She embroidered the tablecloth beautifully.'

d. Они успешно выполнили это задание. 'They successfully completed the mission.'

е. А я правильно это сказал? 'Did I say this correctly?'

f. Она полностью освоилась в новой обстановке. 'She completely got used to the new situation.'

(41') a. He produced an activity that was sufficient for the fact that he is finally grown up.

b. She produced an activity that was sufficient for the fact that she has warm clothes on.

c. She produced an activity that was sufficient for the fact that the tablecloth has beautiful embroidery.

d. They produced an activity that was sufficient for the fact that the results of their work exist successfully for others as an experience.

e. I hereby ask you to commit yourself to the truth or falsity of the following statement: "It is correct what I said". 
f. She produced an activity that was sufficient for the fact that she is completely familiar with the new situation.

Only a small number of adverbials can be used in connection with both aspectual forms without operating on different subdomains:

(42) а. Она читала рассказ вслух. 'She was reading the story aloud.'

b. Она прочитала рассказ вслух. 'She read the story aloud.'

$\left(42^{\prime}\right)$ a. She produced an activity with the intention that it be sufficient for the fact that the story exists loudly for somebody.

b. She produced an activity that was sufficient for the fact that the story exists loudly for somebody.

(43) а. Он дорого продавал старую машину. 'He tried to sell the car at a high price.'

b. Он дорого продал старую машину. 'He sold the car at a high price.'

$\left(43^{\prime}\right)$ a. He produced an activity with the intention that it be sufficient for the fact that the old car is gone with pecuniary benefit.

b. He produced an activity that was sufficient for the fact that the old car is gone with pecuniary benefit.

(44) а. Он уезжает на десять дней. 'He is going away for ten days.'

b. Он уехал на десять дней. 'He went away for ten days.'

$(44 ')$ a. He intends to produce an activity with the intention that it be sufficient for the fact that he is gone for ten days.

b. He produced an activity that was sufficient for the fact that he is gone for ten days. 
The reason why certain temporal adverbials seem to ignore the assertive properties of verbs must be based on the two following points. First, they are very narrow in meaning; secondly, as a consequence of that, they occur with a small number of verbs.

\section{Lexical differences as differences in subdomain}

Having looked at the various examples presented above it should be obvious that members of socalled synonymous groups operate on different subdomains. In other words, it seems to be the case that their differences in lexical meaning can be explained from the point of view of deep syntax. Let us take нечаянно 'inadvertently', невзначай 'by accident', случайно 'accidentally' as illustrative examples. (We base our analysis of these three adverbs on Maier 1998 which is a thorough investigation of them built upon numerous examples from a large data corpus; for another detailed description, see Levontina 2004b).

(45) а. Я нечаянно подслушал ваш разговор. 'I inadvertently overheard your conversation.'

b. Я случайно подслушал ваш разговор. 'I overheard your conversation accidentally.'

с. Я невзначай подслушал ваш разговор. 'I overheard your conversation by accident.'

$\left(45^{\prime}\right)$ a. I produced an accidental activity that was sufficient for the fact that your conversation exists for me as an auditory experience.

b. I produced an activity that was accidentally sufficient for the fact that your conversation exists for me as an auditory experience. 
c. I produced an activity that was sufficient for the fact that your conversation exists for me as an auditory experience, and that you believed that it was by accident.

As appears from the paraphrases, (45a) asserts that the agent did not know what he was doing when he got to hear a conversation between the hearer and another person. Here нечаянно has the activity description as its subdomain and, moreover, it seems, one way or the other, to resemble what could be called first person adverbials. (45b) exemplifies the unspecified use where it is stated that the world was organized in such a way that the speaker heard something that he in fact had not planned or desired to hear. The adverbial случайно operates on the causation description and resembles what could be called third person adverbials. The last example, (45c), is extremely specific. It says that it was intended that the persons involved in the conversation should get the impression that the action performed by the speaker was purely accidental. The adverbial невзначай operates on the state description and can be said to resemble what could be called second person adverbials (for more on this see Durst-Andersen and Lorentzen 2015). Let us take some more examples:

(46) а. Иван серьезно заболел. 'Ivan became seriously ill.'

b. Иван всерьез заболел. 'Ivan has really become ill.'

(46') a. Something produced an activity that was sufficient for the fact that Ivan is seriously ill.

b. Something produced an activity that was really sufficient for the fact that Ivan is ill.

As appears from the numerous examples in Maier 1995, всерьез is uniform, whereas серьезно is multiform. In other words, the former can only have the causation description as its subdomain 
(for that reason *Иван всерьез болеет, which lacks a causation description, is ungrammatical), while the latter has several possibilities. It can be used as a sentence adverbial (se DurstAndersen and Lorentzen 2015), and it can operate on the entailment structure, the activity description, the causation description, and the state description (cf. 13 and 46a). We emphasize that the uniform / multiform dichotomy should not be confused with the marked / unmarked one. There is a great difference between these two sets of notions. It is true that what is uniform has only one meaning and what is multiform has several meanings, but the point is that what is multiform can never substitute for what is uniform: серьезно can never substitute for всерьез as would have been the case if it had been unmarked.

This type of analysis can be extended to other synonymous groups, for instance:

- неловко 'uncomfortably, awkwardly', неуклюже 'clumsily', and неудобно 'inconveniently, uncomfortably';

- умело 'skilfully, cleverly', удачно 'successfully, well', успешно 'successfully';

• внимательно 'attentively', подробно 'in detail', тщательно 'thoroughly';

- намеренно 'intentionally', умышленно 'deliberately', нарочно 'on purpose'.

In the examples below we shall use the same verb for all members of a synonymous group although we are fully aware that different verbs attract different adverbials. We do this for illustrative purposes.

(47) а. Он неловко сел. 'He sat down awkwardly.'

b. Он неуклюже сел. 'He sat down clumsily.'

с. Он неудобно сел. 'He sat down uncomfortably.' 
In (47a) it is stated that the agent was in a state of being awkward when he performed the activity. In (47b) it is not the agent, but the activity itself that appears to be clumsy, and in (47c) we are told that the agent feels that he is sitting in an uncomfortable position. The differences seem to be explainable if the three adverbials are placed in the entailment structure, the activity description and the state description, respectively:

(47') a. He was uncomfortable as he produced an activity that was sufficient for the fact that he exists in a sitting position.

b. He produced an uncomfortable activity that was sufficient for the fact that he exists in a sitting position.

c. He produced an activity that was sufficient for the fact that he exists in an uncomfortable sitting position.

We witness the same differences when we turn to the following examples:

(48) а. Молодой хирург умело провел сложную операцию. 'The young surgeon skilfully performed a complex operation.'

b. Молодой хирург удачно провел сложную операцию. 'The young surgeon performed a complex operation in a skilled manner.'

с. Молодой хирург успешно провел сложную операцию. 'The young surgeon performed a complex operation with success.'

(48a) talks about the agent, (48b) about the activity, and (48c) about the state description. If the reader concludes from hearing (48b) that the surgeon's performance was a success, it has nothing to do with the meaning of the sentence - it will be a conversational implicature. The same will be true of (48c). Here the reader is tempted to think that the successful state was the result of a wellperformed activity. 
(48') a. The surgeon was skilful as he produced an activity that was sufficient for the fact that the damage is repaired.

b. The surgeon produced a skilful activity that was sufficient for the fact that the damage is repaired.

c. The surgeon produced an activity that was sufficient for the fact that the damage is repaired skilfully.

Let us proceed to the next synonymous group which involves внимательно 'attentively', подробно 'in detail', тщательно 'thoroughly':

(49) а. Следователь внимательно изучил дело. 'The detective examined the case attentively.'

b. Следователь подробно изучил дело. 'The detective examined the case in detail.'

с. Следователь тщательно изучил дело. 'The detective examined the case thoroughly.'

Again one can say that (49a) speaks about the agent, (49b) about the activity itself, and (49c) about the state:

(49') a. The detective was attentive in detail as he produced an activity that was sufficient for the fact that he knows the case.

b. The detective produced a detailed activity that was sufficient for the fact that he knows the case.

c. The detective produced an activity that was sufficient for the fact that he knows the case in detail. 
The final group to be examined includes adverbs that are particularly interesting from the point of view of criminal law (For a detailed description of these and related adverbials, see Levontina 2004a):

(50) а. Он умышленно разбил вазу. 'He deliberately (premeditatedly) broke the vase.'

b. Он намеренно разбил вазу. 'He intentionally broke the vase.'

с. Он нарочно разбил вазу. 'He broke the vase on purpose.'

In (50a) it is said that the agent was fully aware of what he was doing when performing the activity that caused the vase to be broken. In (50b) it is stated that somebody had an intention when he broke the vase, but the point is that his intention was not necessarily to break the vase, but, for instance, to make his wife sorry or to make himself happy by breaking it. In (50c) we are told that when the person produced the activity he indeed had the intention of breaking the vase but we are not told that the agent had planned it beforehand.

$\left(50^{\prime}\right)$ a. He was fully aware of what he intended to do when he produced an activity that was sufficient for the fact that the vase as a vase does not exist on world-location anymore.

b. He produced an intended activity that was sufficient for the fact that the vase as a vase does not exist on world-location anymore.

c. He produced an activity that was intended to be sufficient for the fact that the vase as a vase does not exist on world-location anymore.

This deep syntactic analysis in fact throws light on the lexical-grammatical meaning of adverbials. It enables us to explain why we find so-called synonymous groups consisting of two or three members. It also makes it possible to explain why certain verbs naturally co-occur with certain adverbials and are felt more or less inappropriate in connection with other adverbials. 


\section{Concluding remarks}

Non-sentence adverbials in Russian were classified, defined and interpreted according to four propositional structures identified in Russian, viz. state descriptions, activity descriptions, event descriptions, and process descriptions.

State descriptions and activity descriptions enter into two simple statement models which take care of all imperfective simplex verbs as well as all perfective and imperfective procedural verbs derived from the basic imperfective state and activity verbs. It was demonstrated that all activity descriptions logically entail a certain state description corresponding to the state in reality that is a necessary precondition for producing an activity. In several places it became evident that the entailment structure plays an important role in syntax and semantics: it can be used to separate adjuncts from complements, it shows that so-called subject disjuncts should not be considered to be external to the propositional structure itself, i.e. they are not at all sentence adverbials, but non-sentence adverbials, and it allows us to distinguish so-called absolute uses of adverbial participles from action descriptions. Moreover, opaque ways of verbalizing states of affairs in Russian became transparent by paraphrasing them as state descriptions in the entailment structure.

Event descriptions and process descriptions are created by perfective and imperfective action verbs, respectively, i.e. those verbs that comprise purely aspectual pairs. They function as standard statement models for all perfective and all imperfective action verbs. They were used to describe why certain adverbials have different meanings when they appear with perfective and imperfective forms. Moreover, because both statement models consist of four interrelated subdomains, they could also be used to demonstrate the exact contribution from a specific adverbial to the meaning conveyed by the entire utterance. The paraphrases deriving from the 
statement models allowed us to define the exact domain of an adverbial, its scope, and its subdomain possibilities corresponding to its possible meanings, i.e. its meaning potential. They also allowed us to describe the way a particular adverb differs from other adverbs belonging to the same synonymous group. It appeared that members of various synonymous groups differ from one another with respect to subdomain, i.e. their differences in meaning are basically reflexes of originally deep syntactic differences. In that way, the four propositional structures seem not only to have descriptive power, but also explanatory value.

\section{References}

Apresjan, Jurij D. 1974. Leksičeskaja semantika: Sinonimičeskie sredstva jazyka. Moskva: Nauka. . 1980. Tipy informacii dlja poverchnostno-semantičeskogo komponenta modeli 'Smysl

$\Leftrightarrow$ Tekst'. (Wiener Slawistischer Almanach Sonderband 1). Wien: Institut für Slawistik der Universität Wien.

. 2006. “Osnovanija sistemnoj leksikografii”. In Jazykovaja kartina mira i sistemnaja

leksikografija, edited by Ju. D. Apresjan. Moskva: Jazyki slavjanskich kul’tur, 31-160.

Apresjan, Jurij D., Igor’’ M. Boguslavskij, Leonid L. Iomdin and Vladimir Z. Sannikov. 2010. Teoretičeskie problemy russkogo sintaksisa. Vzaimodejstvie grammatiki i slovarja. Moskva: Jazyki slavjanskich kul’tur.

Apresjan, Valentina Ju. 1997. “Semantika i ee refleksy u narečij usilija i maloj stepeni”. Voprosy jazykoznanija 5:16-34. 
Apresjan, Valentina Ju. 2004. “S trudom, nasilu, ele 1, edva 1, čut' 2". In Novyj ob’jasnitel nyyj slovar' sinonimov russkogo jazyka. (NOSSRJa), edited by Jurij D. Apresjan (2-e izd., ispr. i dop.). Wiener Slavistischer Almanach (Studia philologica). Moskva, Vena, 1118-1122.

Austin, Jennifer R., Stefan Engelberg and Gisa Rauh, eds. 2004. Adverbials. The Interplay between Meaning, Context, and Syntactic Structure. Philadelphia, PA, USA: John Benjamins.

Babajceva, Vera V. and Leonard Ju. Maksimov. [1981] 1987. Sovremennyj russkij jazyk. Učebnik dlja pedagogičeskich institutov po spec. 2101 "Russkij jazyk i literatura" v 3 častjach. Čast’ 3. Sintaksis. Punktuacija. 2-e izd., pererab. Moskva: Prosveščenie.

Bartsch, Renate. 1976. The Grammar of Adverbials: A Study in the Semantics and Syntax of Adverbial Constructions. Translated from German by Ferenc Kiefer. Amsterdam, New York: North-Holland Publishers. / 1972. Adverbialsemantik. Die Konstitution logischsemantische Repräsentationen von Adverbialkonstruktionen. Linguistische Forschungen, Bd. 6, Frankfurt/M.: Athenäum.

Belošapkova, Vera A. et al. [1981] 1997. Sovremennyj russkij jazyk: Učebnik dlja filologičeskich special'nostej vysšich učebnych zavedenij. 3-e izd., ispr. i dop. Moskva: Azbukovnik.

Boguslavskij, Igor' M. 1996. Sfera dejstvija leksičeskich edinic. Moskva: Jazyki russkoj kul’tury. . 2008. "Aktantnoe povedenie adverbial'nych derivatov". In Dinamičeskie modeli.

Slovo. Predloženie. Tekst. Sbornik statej v čest’ E. V. Padučevoj, edited by Aleksandr Bondarenko, Galina Kustova and Raisa Rozina. Moskva: Jazyki slavjanskich kul'tur, 110128.

Bondarko, Aleksandr V. 1983. Principy funkcional'noj grammatiki $i$ voprosy aspektologii. Leningrad: Nauka. 
Corver, Norbert and Denis Delfitto. 2000. "Introduction: on Adverbs and Adverbial Modification". Italian Journal of Linguistics 12, no.1:3-11.

Chrakovskij, Viktor S. 1998. "Ponjatie sirkonstanta i ego status". Semiotika i informatika 36: $141-153$.

. 2012. "Verbocentričeskij podchod k konstrukcijam i/ili grammatika konstrukcij". In Smysly, teksty $i$ drugie zachvatyvajuščie sjužety. Sbornik statej v čest' 80-letija I. A. Mel'čuka. Moskva: Jazyki slavjanskoj kul'tury, 288-300.

Cresswell, Max J. 1985. Adverbial Modification. Interval Semantics and Its Rivals. Dordrercht: D. Reidel.

Davidson, Donald. 1967. “The Logical Form of Action Sentences”. In The Logic of Decision and Action, edited by Nicholas Rescher. Pittsburg, PA: University of Pittsburg Press, 81-95.

Durst-Andersen, Per. 1992. Mental Grammar. Russian Aspect and Related Issues. Columbus, Ohio: Slavica Publishers.

. 1994. "Russian Aspect as Different Statement Models". In Tense, Aspect, Action: Empirical and Theoretical Contributions to Language Typology, edited by Carl Bache, Hans Basbøll and Carl-Erik Lindberg. Berlin and New York: Mouton de Gruyter, 81-112. 2011. Linguistic Supertypes. A Cognitive-Semiotic Theory of Human Communication. Berlin, New York: De Gruyter Mouton.

Durst-Andersen, Per and Elena Lorentzen. 2015. "Russian Sentence Adverbials: Classification, Orientation and Representation". Russian Linguistics 39:33-62.

Evseeva, Irina V., T. A. Luzgina, I. A. Slavkina and F. V. Stepanova. 2007. Sovremennyj russkij jazyk: Kurs lekcij, edited by Inga A. Slavkina. Krasnojarsk: Sibirskij federal'nyj universitet. Filipenko, Marina V. 1998. “Ob adverbialach s plavajuščej i fiksirovannoj sferoj dejstvija (k voprosu ob aktantach i ne-aktantach predikata)". Semiotika i informatika 36:120-139. 
. 2003. Semantika narečij i adverbial'nych vyraženij. Moskva: Azbukovnik.

Glovinskaja, Marina Ja. 1982. Semantičeskie tipy vidovych protivopostavlenij russkogo glagola. Moskva: Nauka.

Greenbaum, Sidney. 1969. Studies in English Adverbial Usage. London: Longmans.

Grigor'eva, S. A. 2004. "Polnost'ju, celikom 2". In Novyj ob jasnitel'nyj slovar' sinonimov russkogo jazyka. (NOSSRJa), edited by Jurij D. Apresjan (2-e izd., ispr. i dop.). Wiener Slavistischer Almanach (Studia philologica). Moskva, Vena, 784-787.

Hasselgård, Hilde. 2010. Adjunct Adverbials in English. Cambridge: Cambridge University Press.

Iordanskaja, Lidija N. and Igor A. Mel’čuk. 1996. "K semantike russkich pričinnych predlogov (IZ-ZA ljubvi OT ljubvi IZ ljubvi * S ljubvi PO ljubvi)”. Moskovskij lingvističeskij žurnal 2:162-211.

Jackendoff, Ray. 1972. Semantic Interpretation in Generative Grammar. Cambridge, MA: The MIT Press.

Jakobson, Roman. [1957] 1971. "Shifters, Verbal Categories and the Russian Verb". In Collected Writings II: Word and Language. The Hague and Paris: Mouton de Gruyter, 130147.

Jespersen, Otto. 1924. The Philosophy of Grammar. London: G. Allen \& Unwin.

Kobozeva, Irina M. 2000. Lingvističeskaja semantika. Moskva: Ėditorial URSS.

Lang, Ewald, Claudia Maienborn and Cathrine Fabricius-Hansen, eds. 2003. Modifying Adjuncts. Berlin: Walter de Gruyter.

Lekant, Pavel A., Elena I. Dibrova, Leonid L. Kasatkin and Evgenij V. Klobukov. [2013] 2015. Sovremennyj russkij jazyk. Učebnik dlja akademičeskogo bakalavriata, edited by Pavel A. Lekant, 5-e izdanie. Moskva: Jurait (Urait). 
Levontina, Irina B. 2004a. "Namerenno, naročno 1, prednamerenno, umyšlenno, soznatel'no 2, special'no 1, celenapravlenno". In Novyj ob jasnitel'nyj slovar' sinonimov russkogo jazyka. (NOSSRJa), edited by Jurij D. Apresjan (2-e izd., ispr. i dop.). Wiener Slavistischer Almanach (Studia philologica). Moskva, Vena, 593-597.

Levontina, Irina B. 2004b. "Nevol'no, nečajanno 1, slučajno 2, nenarokom, nevznačaj, neproizvol'no". In Novyj ob jasnitel'nyj slovar' sinonimov russkogo jazyka. (NOSSRJa), edited by Jurij D. Apresjan (2-e izd., ispr. i dop.). Wiener Slavistischer Almanach (Studia philologica). Moskva, Vena, 628-632.

Litnevskaja, Elena I. 2006. Russkij jazyk: kratkij teoretičeskij kurs dlja škol'nikov. http://gramota.ru/book/litnevskaya.php. Accessed 29 January 2015.

Lyons, John. 1977. Semantics. Vol. I, II. Cambridge: Cambridge University Press.

McCawley, James D. [1981] 1993. Everything That Linguists Have Always Wanted to Know about Logic. 2nd edition. Chicago: The University of Chicago Press.

Maienborn, Claudia and Martin Schäfer. 2011. "Adverbs and Adverbials". In Semantics: an International Handbook of Natural Language Meaning, edited by Claudia Maienborn, Klaus von Heusinger and Paul Portner. Vol. 2. Berlin, Boston: Walter de Gruyter, 1390-1420.

Maier, Ingrid. 1995. “'Allvarligt' på ryska”. Slovo 44:63-88. 1998. "Russkie narečija so značeniem ‘slučajno, nečajanno"”. Slovo 46:5-29.

Mel'čuk, Igor' A. 1974. Opyt teorii lingvističeskich modelej 'Smysl $\Leftrightarrow$ Tekst'. Čast' 1. Semantika, sintaksis. Moskva: Nauka. 2015. Semantics. From Meaning to Text. Vol. 3. Amsterdam, Philadelphia: John Benjamins B. V. 
Mittwoch, Anita. 2001. "Perfective Sentences under Negation and Durative Adverbials: A Double-jointed Construction". In Perspectives on Negation and Polarity Items, edited by Jack Hoeksema, Hotze Rullmann, Víctor Sánchez-Valencia and Ton van der Wouden. Amsterdam \& Philadelphia PA: John Benjamins, 265-282.

Musan, Renate. 2002. The German Perfect. Its Semantic Composition and its Interaction with Temporal Adverbials. Dordrecht, NL: Kluwer Academic Publishers.

Nølke, Henning. 1978. "Problemer ved opstillingen af en typologi for de franske adverbialled". RIDS 57, Københavns Universitet.

Padučeva, Elena V. 1977. "Ponjatie prezumpcii i ego lingvističeskie primenenija". Semiotika $i$ informatika 8:91-124.

1999. "Princip kompozicionnosti v neformal'noj semantike". Voprosy jazykoznanija

\section{$5: 3-23$.} . 2004. Dinamičeskie modeli v semantike leksiki. Moskva: Jazyki slavjanskoj kul’tury. . 2011. "Prezumpcija". In Materialy dlja proekta korpusnogo opisanija russkoj

grammatiki. Na pravach rukopisi. Moskva: http://rusgram.ru. Accessed 29 January 2015.

Plungjan, Vladimir A. and Ekaterina V. Rachilina. 1990. “Sirkonstanty v tolkovanii?”. In Metody formalne w opisie języków słowiańskich (k 60-letiju Ju. D. Apresjana), edited by Zygmunt Saloni. Białystok: Dzial Wydawn. Filii UW w Białymstoku, 201-210.

Prokopovič, Elena N. 1982. Glagol v predloženii: semantica i stilistika vido-vremennych form. Moskva: Nauka.

Quirk, Randolph, Sidney Greenbaum, Geoffrey Leech and Jan Svartvik. 1985. A Comprehensive Grammar of the English Language. London and New York: Longman. 
Rudnickaja, Elena L. 1994. "Nekotorye klassy sentencial'nych narečij v russkom jazyke. Semantika. Sintaksis. Leksikografija”. Voprosy jazykoznanija 1:114-125.

Šeljakin, Michail A. 1993. Spravočnik po russkoj grammatike. Moskva: Russkij jazyk.

Sirotinina, Ol’́ga B. [1980] 2006. Lekcii po sintaksisu russkogo jazyka. 3-e izd., dop. (Serija: Lingvističeskoe nasledie XX veka). Moskva: Ėditorial URSS, KomKniga.

Švedova, Natalija Ju. 1964. "Determinirujuščij ob" ekt i determinirujuščee obstojatel'stvo kak samostojatel'nye rasprostraniteli predloženija”. Voprosy jazykoznanija 6:77-93. 1968. "Suščestvujut li vse-taki determinanty kak samostojatel’nye rasprostraniteli predloženija?”. Voprosy jazykoznanija 2:39-50. , et al. 1980. Russkaja grammatika. Tom 1, 2. Moskva: Nauka.

Švedova, Natalija Ju., Vladimir V. Lopatin et al. [1989] 2002. Kratkaja russkaja grammatika. Moskva.

Swan, Toril. 1988. Sentence Adverbials in English: A Synchronic and Diachronic Investigation. Oslo: Novus Forlag.

Tesnière, Lucien. 1959. Éléments de syntaxe structurale. Paris: Éditions Klincksieck.

Testelets, Jakov G. 2001. Vvedenie v obščij sintaksis. Moskva: RGGU.

Valgina, Nina S. [1973] 2003. Sovremennyj russkij jazyk. Sintaksis: Učebnik dlja vuzov. Izdanie 4-e, ispravlennoe. Moskva: Vysšaja škola.

Voskresenskaja, Ekaterina O., Elizaveta M. Tkačenko and Natalija V. Slautina. 2013. EGE. Russkij jazyk: universal'nyj spravočnik. Moskva: Jauza-press.

Zvegincev, Vladimir A. 1976. Predloženie i ego otnošenie k jazyku i reči. Moskva: Izdatel’stvo Moskovskogo universiteta. 